\title{
Analisis Hubungan Antar Manusia terhadap Kinerja Karyawan
}

\author{
Abdul Latief*, Dhian Rosalina \& Devi Apiska \\ Fakultas Ekonomi Universitas Samudra \\ Diterima: Januari; Disetujui: Januari; Dipublish: April \\ *E-mail: latief@unsam.ac.id
}

\begin{abstract}
Abstrak
Penelitian ini bertujuan untuk mengetahui pengaruh hubungan antar manusia terhadap kinerja karyawan PT Perkebunan Timbang Langsa. Penelitian ini merupakan jenis penelitian kuantitatif deskriptif dengan sampel sebanyak 134 responden. Teknik pengambilan sampel pada penelitian ini menggunakan Probability Sampling dan penentuan sampel dilakukan secara random sampling. Metode analisis data yang digunakan adalah analisis regresi linier sederhana. Uji hipotesis yang dilakukan melalui uji parsial (uji t) dan uji koefisien determinasi $\left(R^{2}\right)$. Hasil persamaan regresi diperolehY $=2,687$ + 0,375X1.Nilai konstanta adalah sebesar 2,687 merupakan nilai kinerja karyawan sebelum dipengaruhi oleh hubungan antar manusia.Koefisien regresi hubungan antar manusia bernilai 0,375 dan bertanda positif, artinya apabila hubungan antar manusia ditingkatkan sebesar satu satuan maka kinerja karyawan akan meningkat sebesar 0,375. Hubungan antar manusia berpengaruh positif dan signifikan terhadap kinerja karyawan pada PT Perkebunan Timbang Langsa dengan hasil uji t yaitu nilai $t_{\text {hitung }}>t_{\text {tabel }}(5,573>1,656)$ dan nilai $t$ sig yaitu $0,000<0,05$. Nilai koefisien determinasi $\left(R^{2}\right)$ yaitu 0,19 0atau 19,0\%. Hal ini menunjukkan variabel hubungan antar manusia mempengaruhi kinerja karyawan pada PT. Perkebunan Timbang Langsa sebesar 19,0\%, dan sisanya 81,0\% dipengaruhi oleh variabel lain yang tidak diteliti dalam penelitian ini, seperti motivasi dan kompensasi.
\end{abstract}

Kata Kunci: Hubungan Antar Manusia, Kinerja, Sumberdaya Manusia

\begin{abstract}
This study aims to determine the effect of human relations on the performance of PT Perkebunan Limbang's employees. This research is a type of descriptive quantitative research with a sample of 134 respondents. The sampling technique in this study uses Probability Sampling and sample determination is done by random sampling. The data analysis method used is simple linear regression analysis. Hypothesis testing is done through partial tests ( $t$ test) and test coefficient of determination (R2). The results of the regression equation obtained $Y=2.687+0.375 X 1$. The value of constant is 2.687 is the value of employee performance before it is influenced by relationships between humans. increased by 0.375 . Relations between humans have a positive and significant effect on the performance of employees at PT Perkebunan Limbang with the results of the test which is the value of tcount> ttable (5.573>1.656) and the value of $t$ sig is $0.000<0.05$. The coefficient of determination (R2) is 0.190 or $19.0 \%$. This shows the variable relations between humans affect the performance of employees at PT. Weighing Langsa Plantation is $19.0 \%$, and the remaining $81.0 \%$ is influenced by other variables not examined in this study, such as motivation and compensation.
\end{abstract}

Keywords: Inter-Human Relations, Performance, Human Resources

How to Cite: Latief, A. Rosalina, D. \& Apiska, D. (2019). Analisis Hubungan Antar Manusia terhadap Kinerja Karyawan. Journal of Education, Humaniora and Social Sciences (JEHSS). 1 (3): 127-131.

\section{PENDAHULUAN}

Sumber daya manusia adalah aset yang mempunyai peran penting dalam kemajuan sebuah perusahaan. Hal ini dikarenakan sumber daya manusia adalah pihak yang menjalankan roda kehidupan perusahaan. Dalam mencapai tujuan perusahaan, setiap perusahaan dituntut untuk 
selalu melakukan banyak perubahan diberbagai bidang khususnya sumber daya manusia. Salah satu hal terpenting yang berkaitan dengan sumber daya manusia adalah permasalahan kinerja. Dalam mewujudkan keberhasilan sebuah perusahaan, setiap karyawan dituntut untuk memiliki kinerja yang baik. Effendy (2009) menyatakan hubungan antar manusia merupakan komunikasi persuasif yang dilakukan oleh seseorang kepada orang lain secara tatap muka dalam situasi kerja dan dalam organisasi dengan tujuan untuk meningkatkan semangat dalam bekerja dan bekerjasama agar dapat mencapai hasil yang memuaskan. Dengan seringnya melakukan komunikasi yang baik antar sesama karyawan, maka secara langsung maupun tidak langsung dapat mempengaruhi kinerja karyawan. Ini bisa langsung dirasakan bahwa komunikasi yang baik dapat semakin membentuk saling perduli maupun saling mendukung antara sesama karyawabn.

Hubungan antar manusia adalah suatu hubungan kemanusiaan yang harmonis, tercipta atas kesadaran dan kesediaan melebur keinginan individu demi terpadunya keinginan bersama (Hasibuan, 2009).. Dalam sebuah perusahaan, karyawan dituntut untuk memiliki hubungan kemanusiaan yang baik, yang diantaranya adalah pimpinan maupun kepada sesama karyawan. Hubungan antar manusia (hubungan antar manusia) merupakan hal yang sangat penting dalam meningkatkan kinerja karena berkaitan dengan komunikasi yang meliputi pikiran, perasaan dan kerja sama dalam melakukan pekerjaan. Hal ini dilakukan untuk menciptakan hubungan kerja yang harmonis sehingga karyawan akan merasa nyaman dan fokus dalam melaksanakan tugas dan berdampak positif terhadap kinerja karyawan.

Kinerja adalah hasil kerja secara kualitas dan kuantitas yang dicapai seorang karyawan dalam melaksanakan tugas yang dibebankan kepadanya. Kinerja karyawan yang berkualitas dapat berdampak positif bagi keberlangsungan hidup sebuah perusahaan (Rivai dan Basri, 2012). Selain itu, baik tidaknya suatu kinerja dapat menjadi tolak ukur untuk melakukan pengambilan keputusan yang efektif dan efisien bagi perusahaan. Namun demikian, tidak semua karyawan memiliki kinerja yang berkualitas. Hal ini dikarenakan banyak berbagai faktor yang mempengaruhi kinerja dari setiap karyawan, salah satunya yaitu hubungan antar manusia.

Berdasarkan hasil pengamatan awal pada PT Perkebunan Timbang Langsa diketahui bahwa karyawan sulit meningkatkan kinerja mereka dikarenakan kurangnya kerjasama antar karyawan dalam menjalankan tugas kerja dan masih ada beberapa karyawan lainnya yang merasa akan tersaingi sehingga kurang maksimal dalam memberikan bantuan ataupun pengetahuan kepada karyawan lain.Beberapa rekan kerja yang acuh dan kurang peduli terhadap rekan kerjanya serta masih ada pimpinan yang kurang peduli dan mengenali bawahannya sehingga hubungan di perusahaan tersebut kurang harmonis yang mengakibatkan karyawan kurang maksimal dalam pekerjaannya dan berdampak terhadap kinerja.

Demikian pula halnya terhadap mental kerja yang dimiliki karyawan sangat mempengaruhi kinerja. Hal ini dikarenakan pimpinan yang selalu memberikan tekanan terhadap karyawan untuk terus meningkatakan kinerja namun dengan cara penyampaian yang kurang tepat, tak jarang perkataan dari pimpinan membuat mental karyawan menjadi terpuruk dan membuat karyawan tersebut tidak bersemangat untuk bekerja dan berdampak kurang baik terhadap kinerjanya.

Sedangkan menurut Mahmudi, (2009) terdapat lima faktor yang mempengaruhi kinerja yaitu: (1) Faktor personal atau individu meliputi pengetahuan, keterampilan, kemampuan, kepercayaan diri, kompensasi yang dimiliki oleh setiap individu; (2) Faktor kepemimpinan meliputi kualitas manajer dan pimpinan dalam memberikan dorongan, semangat, arahan dan dukungan kepada individu; (3) Faktor tim yang mencakup kualitas dukungan dan semangat, kepercayaan, keeratan dan kekompakan yang diberikan terhadap sesama anggota tim; (4) Faktor sistem, meliputi sistem kerja, fasilitas kerja, infrastruktur, proses organisasi dan kultur kinerja dalam organisasi; (5) Faktor kontekstual (situasional), meliputi tekanan dan perubahan lingkungan eksternal dan internal 

DOI:

\section{METODE PENELITIAN}

Populasi dalam penelitian ini adalah seluruh karyawan tetap PT. Perkebunan Timbang Langsa yang berjumlah 202 responden. Penentuan jumlah sampel dalam penelitian ini menggunakan rumus Slovin sehingga jumlah sampel yang diambil sebanyak 134 responden.

Teknik pengambilan sampel pada penelitian ini menggunakan Probability Sampling yaitu teknik pengambilan sampel yang memberi peluang atau kesempatan yang sama untuk dipilih menjadi sampel. Untuk menentukan siapa yang akan dijadikan sampel dilakukan secara random sampling. Metode pengumpulan data yang digunakan dalam penelitian ini adalah penelitian lapangan berupa observasi, interview dan kuesioner, dan penelitian kepustakaan. Jenis data yang digunakan berupa data kuantitatif yang diperoleh dari hasil penyebaran kuesioner kepada 134 orang responden dengan pernyataan dalam kuessioner dibuat menggunakan skala 1-5 untuk mewakili pendapat dari responden. Nilai skalalikert tersebut adalah: Sangat Setuju (SS): 5, Setuju (S): 4, Kurang Setuju (KS): 3, Tidak Setuju (TS): 2, Sangat Tidak Setuju (STS): 1.

Metode Analisa data yang digunakan untuk mengetahui variabel bebas terhadap variabel terikat digunakan rumus regresi linier sederhana dengan menggunakan bantuan SPSS Versi 20.0. Model hubungan karyawan dengan variabel-variabel tersebut dapat disusun dalam fungsi persamaan sebagai berikut (Sugiono, 2011:275):

$$
\begin{aligned}
& \mathrm{Y}=\mathrm{a}+\mathrm{b}_{1} \mathrm{X} 1 \\
& \text { Dimana: } \\
& \mathrm{Y}=\text { Kinerja Karyawan } \\
& \mathrm{a}=\text { Konstanta } \\
& \mathrm{b}_{1} \quad=\text { Koefisien regresi variabel X1 } \\
& \mathrm{X} 1 \quad=\text { Hubungan Antar Manusia }
\end{aligned}
$$

Pengujian Hipotesis dalam penelitian ini menggunakan teknik analisis Uji Parsial (Uji t), digunakan untuk menguji signifikansi hubungan antara variabel X dan $Y$, apakah variabel X1 (Hubungan Antar Manusia) benar-benar berpengaruh terhadap Y (Kinerja Karyawan) secara terpisah atau parsial. Koefisien Determinasi $\left(\mathrm{R}^{2}\right)$, dimaksudkan untuk mengetahui tingkat ketepatan paling baik dalam analisa regresi, dimana hal yang ditunjukkan oleh besarnya koefisien determinasi $\left(\mathrm{R}^{2}\right)$ antara $0(\mathrm{nol})$ dan 1 (satu). Koefisien determinasi $\left(\mathrm{R}^{2}\right)$ nol variabel independen sama sekali tidak berpengaruh terhadap variabel dependen. Apabila koefisien determinasi $\left(\mathrm{R}^{2}\right)$ semakin mendekati satu, maka dapat dikatakan bahwa variabel independen berpengaruh terhadap variabel dependen, selain itu koefisien determinasi $\left(\mathrm{R}^{2}\right)$ dipergunakan untuk mengetahui persentase perubahan variabel independen $(\mathrm{Y})$ yang disebabkan oleh variabel dependen $(X)$.

\begin{tabular}{|c|c|c|c|c|c|}
\hline \multicolumn{6}{|c|}{ Koefisien Regresi Linear Sederhana } \\
\hline \multirow[t]{2}{*}{ Model } & \multicolumn{2}{|c|}{$\begin{array}{l}\text { Unstandardized } \\
\text { Coefficients }\end{array}$} & \multirow{2}{*}{$\begin{array}{l}\text { Standardized } \\
\text { Coefficients } \\
\text { Beta }\end{array}$} & \multirow[t]{2}{*}{$\mathrm{T}$} & \multirow[t]{2}{*}{ Sig. } \\
\hline & $\mathrm{B}$ & Std. Error & & & \\
\hline (Constant) & 2.687 & .281 & & 9.569 & .000 \\
\hline Human relation & .375 & .067 & .436 & 5.573 & .000 \\
\hline
\end{tabular}

\section{HASIL DAN PEMBAHASAN}

Berdasarkan hasil pengumpulan data penelitian dan dilakukan pengolahan data dengan bantuan software SPSS di peroleh nilai coeffisien regresi linear sederhana sebagai berikut:

Tabel 4.1

Koefisien Regresi Linear Sederhana

Dengan melihat tabel 4.1 pada kolom nilai Unstandardized Coefficients (B) didapat persamaan regresi linier sederhana untuk penelitian ini adalah $Y=2,687+0,375 X 1$. Dari persamaan regresi tersebut dapat dijelaskan bahwa: nilai konstanta adalah sebesar 2,687 merupakan nilai kinerja karyawan sebelum dipengaruhi oleh variabel hubungan antar manusia. 
Koefisien regresi hubungan antar manusia bernilai 0,375 dan bertanda positif, artinya apabila hubungan antar manusia ditingkatkan sebesar satu satuan maka kinerja karyawan akan meningkat sebesar 0,375.

Hasil uji t atau uji signifikansi variabel hubungan antar manusia terhadap kinerja karyawan dapat diketahui dengan melihat tabel 1 . Pada tabel 1 diketahui nilai t sig yaitu 0,000< 0,05. Dengan demikian dapat dinyatakan bahwa hubungan antar manusiaberpengaruh positif dan signifikan terhadap kinerja karyawan PT. Perkebunan Timbang Langsa. Artinya hipotesis diterima.

Nilai koefisien determinasi $\left(\mathrm{R}^{2}\right)$ dapat dilihat pada tabel 2 berikut:

Tabel 4.2

Model Summary

\begin{tabular}{|l|l|l|l|l|}
\hline Model & R & R Square & Adjusted R Square & \begin{tabular}{l} 
Std. $\begin{array}{l}\text { Error of the } \\
\text { Estimate }\end{array}$ \\
\hline 1
\end{tabular} \\
\hline
\end{tabular}

Berdasarkan tabel 4.2 diketahui nilai koefisien determinasi $\left(\mathrm{R}^{2}\right)$ yaitu 0,190 atau $19,0 \%$. Hal ini menunjukkan variabel hubungan antar manusia mempengaruhi kinerja karyawan pada PT. Perkebunan Timbang Langsa sebesar 19,0\%.

\section{SIMPULAN}

Berdasarkan analisis data dan pembahasan mengenai pengaruh hubungan antar manusia terehadap kinerja karyawan pada PT Perkebunan Timbang Langsa diperoleh simpulan bahwa hubungan antar manusia berpengaruh positif dan signifikan terhadap kinerja karyawan pada PT Perkebunan Timbang Langsa. Hal ini menunjukkan semakin baik hubungan antar karyawan maka akan berdampak baik terhadap peningkatan kinerja karyawan itu sendiri. Nilai koefisien determinasi $\left(\mathrm{R}^{2}\right)$ yaitu 0,19 0atau 19,0\%. Hal ini menunjukkan variabel hubungan antar manusia mempengaruhi kinerja karyawan pada PT. Perkebunan Timbang Langsa sebesar 19,0\%.

\section{DAFTAR PUSTAKA}

Asrifah. (2015). Pengaruh Human Relation terhadap Kinerja Pegawai di Kantor Wilayah Kementrian Agama Provinsi di Sulawesi Tengah. e-Jurnal Katalogis. Vol.3, No.2, Hal: 125-134

Bangun, W. (2012). Manajemen Sumber Daya Manusia, Bandung: Erlangga.

Djaja, D. (2011). Peranan Humas Dalam Perusahaan. Jakarta: Graha Ilmu.

Davis, K. (2009). Perilaku dalam Organisasi. Jakarta: PT. Pustaka Binawan.

Effendy, O.U. (2009). Human Relation danPublic Relation. Bandung: Mandar Maju.

Gibson, J.L dan Ivancevich, John M. (2010). Organisasi, Struktur dan Manajemen.(Terjemahan: Djoerban Wahid, S.H ). Jakarta: Erlangga.

Hasibuan, M. (2009). Manajemen Sumber Daya Manusia, edisi revisi Jakarta: Bumi Aksara.

Jalaludin, R. (2011). Psikologi Komunikasi. Bandung: PT. Remaja Rosdakarya.

Kuncoro, M. (2009). Metode Riset Untuk Bisnis dan Ekonomi. Jakarta, Erlangga.

Kurniati. (2009). Manajemen Sumber Daya Manusia. Jakarta: PT. Raja Grafindo Persada.

Kuswandi, Febriyanti, Rina dan Suryo Chayono. (2015). Pengaruh Human Relation, Iklim Organisasi dan Etos Kerja terhadap Kinerja Pegawai Dinas Pendidikan Kota Banjar Baru. Jurnal Ilmiah Ekonomi Bisnis. Vol.1, No.8, Hal:10-18.

Lungan, R. (2010). Aplikasi Statistika dan Hitung Peluang. Yogyakarta: Graha Ilmu.

Mahmudi. (2009). Manajemen Kinerja Sektor Publik. Yogyakarta: UPP AMP YKPN.

Mangkunegara, A.P. (2011). Manajemen Sumber Daya Manusia Perusahaan. Bandung: PT. Remaja Rosdakarya.

Munasef. (2008). Manajemen Kepegawaian Indonesia. Jakarta: PT. Gunung Agung.

Rivai, V, Basri, A.F.M. (2012). Performance Appraisal. Jakarta: PT. Raja Grafindo Persada.

Rukmana, W.E. (2010). Analisis Pengaruh Human Relation (Hubungan Antar Manusia) Dan Kondisi Fisik Lingkungan Terhadap Etos Kerja Dan Kinerja Karyawan Dedy Jaya Plaza Tegal. Skripsi. Universitas Dipenogoro. Semarang. 
Sedarmayanti. (2009). Manajemen Sumber Daya Manusia, Reformasi Birokrasi dan Manajemen Pegawai Negeri Sipil. Bandung: PT. Refika Aditama.

Siagian, S. P. (2012). Kiat Meningkatkan Produktivitas Kerja. Jakarta: PT Rineka Cipta.

Simamora, H. (2008). Manajemen Sumber Daya Manusia. Yogyakarta: STIE YKPN.

Simanjuntak, P.J. (2010). Manajemen dan Evaluasi Kinerja. Jakarta: FEUI

Sugiyono. (2014). Metode Penelitian Kuantitatif Kualitatif dan R\&D. Bandung: Alfabeta.

Susanti, Eka Cahyana Putri, Al Musadieq Mochammad dan Ika Ruhanna. Pengaruh Human Relation (Hubungan Antar Manusia dan Kondisi Lingkungan Kerja terhadap Kinerja Karyawan. Jurnal Administrasi Bisnis. Vol.17, No.2, Hal:1-9

Talumantak, Angreini, Kojo, Christoffel dan Lucky Dotulang. (2016). Analisis Pengaruh Human Relationship dan Beban Kerja terhadap Kinerja Pegawai pada Dinas Koperasi dan UMKM Provinsi Sulawesi Utara. Jurnal Berkala Ilmiah Efisiensi. Vol.16, No. 01, Hal:852-862

Umar, H, (2009). Manajemen Sumber Daya Manusia, Jakarta: Rineka Cipta.

Wibowo. (2012). Manajemen Kinerja. Jakarta: Rajawali Perss. 